\section{村落内住居様式の移動調查法}

立川稀士

最近では，一村落内に，建築様式の異なる， 種々の住居が混在しているのが普通になった。 そこで，いままでの民家の研究で行なわれてい、 たような，個別の住居の調査によって村落内の 住居を代表させるといら考え方ではなく，種々 の建築様式をるつ住居を混在したままの姿でと らえる必要があり，そのためには全数調査を行 ならことが望ましい。しかし、これには多くの 時間と労力を必要とする。そこで筆者は，この 睢点を幾分なりとも解消するため, 調査項目を $2 \cdot 3$ の要索に限り, 数村落の簡便な調査を行な い,その得失を考えた。

この方法は自動車に 4 人が乗車し, 後の座席 の 2 人がそれぞれ道の片側の住居の建築様式を 配列順に判断し，分類に従って声を出して知ら せる。助手席のスクリプターはそれをメモして いく。フィールドノートの右ベージ下から書い ていくと，集落を通過した時には個々の住居の， たとえば屋根形・位置・配列などが書かれるこ とになる（非住居一公共建箱物・执屋などーは調查加 ら除いた)。車速は $20 〜 30 \mathrm{~km} / \mathrm{h}$ が適当である。 慣れるとスクリブターは，自分です住居を見， 後の 2 人の声を確認の助けとしながら記入でき る。
猪苗代湖の西岸, 茨城街道ぞい(小䛀〜殹場)を 調査 (1972.7.5. 実施) したが，そのらち会津若 松市赤井について，模式図を示した。ここでは 屋根の形と材料の 2 要素のみを調べた。組合せ 総数は9つであるが, 赤井にはそのらち7つが みられた (表)。ところで，たとえばトタン寄 棟といっても，かやふきの上からトタンをかふ せた型式と、より勾配のゆるい，はじめからト タンぶきで建てたものとが識別されず，かや寄 棟の中にもシンブルなるのと半切妻が混しって いる状態で，この簡易調查では，いまた村落の 複雑な外観を十分には再現し得ていない。

この方法の得失をまとめると：

(1) 道路に面してたけ 住居のある村落では 使えるが，塊村状になると全数調査は不可能で ある。

（2）ききのがし・見のがし・重復して数え るおそれ・などがあり，それをチェックする手 段がない。

（3）一度に3つ以上の要素を 調べるのは困 難である。

（4）一方，歩いて調べるよりは，かなり広い 地域を比較的速く，数的におさえることができ るので，予察としての効果は十分に期待できる と思われる（上記小坂～桭場間 8 村落を調べのに約 40 分で耛わった。

(1972.8.1 受理)

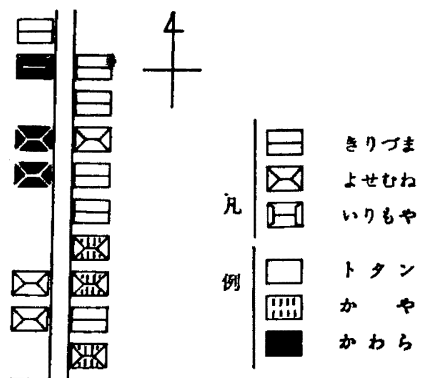

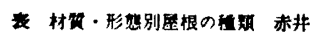

\begin{tabular}{|c|c|c|}
\hline & 户 数 & $\%$ \\
\hline トタン寺槒 & 13 & 22.8 \\
\hline トタン切装 & 10 & 17.5 \\
\hline トタン入册座 & 9 & 15.8 \\
\hline か p客 拣 & 11 & 19.3 \\
\hline 加中切言 & 5 & 8.8 \\
\hline からら楮 & 5 & 8.8 \\
\hline かから入在展 & 4 & 7.0 \\
\hline 竍 & 57 & 100.0 \\
\hline
\end{tabular}

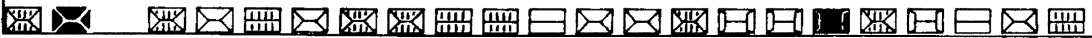

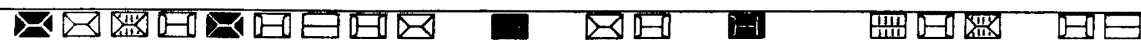

家の向きは調べていないのて，一応すべて南向きに建っているように表示した。

調査は東北大学地理学教室の 3 年生諸氏に手伝っていただいた

\title{
Methodology for Observation of House Types Shigeo TACHIKAWA
}

In order to undertstand aspects of houses in today's settlement it is important to be able to observe house types speedily and extensively. One method is to utilize the automobile. Using a pre-determined classification scheme, two observers may rapidly relay the data to a third person for recording. This method appears to be useful for a preliminary study. 